ЭКСПРЕССИЯ ТКАНЕВЫХ ИНГИБИТОРОВ МЕТАММОПРОТЕИНАЗ

ТИПА 1 И 2 В СТВОРКАХ ЭКСПААНТИРОВАННЫХ

БИОПРОТЕЗОВ КААПАНОВ СЕРАЦА - НОВАЯ

ПАТОГЕНЕТИЧЕСКАЯ ПАРАМАЕАЬ МЕЖАУ СТРУКТУРНОЙ

АЕГЕНЕРАЦИЕЙ КААПАНА И КААЬЦИНИРУЮЩИМ

АОРТААЬНЫМ СТЕНОЗОМ

\author{
А.Е. Костюнин, Т.В. Глушкова, Л.А. Богданов, Е.А. Овчаренко \\ ФГБНУ «Научно-исслеАовательский институт комплексных проблем серАечно-сосудистых \\ заболеваний», Кемерово, Российская Фелерация
}

\begin{abstract}
Цель: изучить клеточную и липидную инфильтрацию, а также экспрессию тканевых ингибиторов металлопротеиназ (ТИМП) типа 1 и 2 в створках биологических протезов клапанов сердца (БПК), эксплантированных по причине дисфункций. Материал и методы. Исследовано 17 створок от 6 БПК, иссеченных из аортальной и митральной позиций при репротезировании клапанов. Для выполнения микроскопического анализа фрагменты створок БПК замораживали и с помощью криотома изготавливали серийные срезы. С целью изучения клеточной инфильтрации и степени дегенеративных изменений протезного биоматериала срезы окрашивали гематоксилином Джилла и эозином, для оценки отложения липидов использовали окраску Oil Red. С целью типирования клеток и выявления ТИМП-1/-2 применяли иммуногистохимический метод. Анализ окрашенных образцов осуществляли методом световой микроскопии. Результаты. Клеточная и липидная инфильтрация ксенотканей выявлена во всех исследованных створках БПК. Клетки реципиентов коэкспрессировали панлейкоцитарный и макрофагальный маркеры PTPRC/CD45 и CD68. Положительная окраска на ТИМП-1/-2 солокализовалась с клеточными скоплениями, но отсутствовала в бесклеточных участках. Заключение. Клетки, проникающие в ксеногенные ткани БПК, экспрессируют ТИМП-1/-2. Это указывает на частичное сходство патофизиологии иммунного отторжения БПК с таковой кальцинирующего аортального стеноза.
\end{abstract}

Ключевые слова: биопротезы клапанов сердия, структурная дегенерачия клапана, кальцинирующий аортальный стеноз, клеточная инфильтрачия, липиды, тканевые ингибиторы металлопротеиназ.

\title{
EXPRESSION OF TISSUE INHIBITORS OF METALLOPROTEINASES TYPE 1 AND TYPE 2 IN THE LEAFLETS OF EXPLANTED BIOPROSTHETIC HEART VALVES: A NEW PATHOGENETIC PARALLEL BETWEEN STRUCTURAL VALVE DEGENERATION AND CALCIFIC AORTIC STENOSIS
}

\author{
A.E. Kostyunin, T.V. Glushkova, L.A. Bogdanov, E.A. Ovcharenko \\ Research Institute for Complex Issues of Cardiovascular Diseases, Kemerovo, Russian Federation
}

Objective: to study cellular and lipid infiltration, as well as the expression of tissue inhibitors of metalloproteinases (TIMP) types 1 and 2 in biological prosthetic heart valves (BPHVs) explanted due to dysfunction. Material and Methods. We examined 17 leaflets from 6 BPHVs, dissected from the aortic and mitral positions during valve replacement. For microscopic analysis, fragments of the BPHV leaflets were frozen and serial sections were made

Для корреспонденции: Костюнин Александр Евгеньевич. Адрес: 650002, Кемерово, Сосновый бульвар, 6.

Тел. (900) 108-10-97. E-mail: rhabdophis_tigrina@mail.ru

Corresponding author: Alexander Kostyunin. Address: 6, Sosnovy Boulevard, Kemerovo, 650002, Russian Federation.

Phone: (900) 108-10-97. E-mail: rhabdophis_tigrina@mail.ru 
using a cryotome. In order to study cellular infiltration and the degree of degenerative changes in the prosthetic biomaterial, the sections were stained with Gill's hematoxylin and eosin; Oil Red O stain was used to assess lipid deposition. Immunohistochemistry was used for cell typing and detection of TIMP-1/-2. The stained samples were analyzed by light microscopy. Results. Cellular and lipid infiltration of xenogeneic tissues was detected in all BPHV flaps studied. Recipient cells coexpressed pan-leukocyte and macrophage markers PTPRC/CD45 and CD68. Positive staining for TIMP-1/-2 co-localized with cell clusters but was absent in acellular sections. Conclusion. Cells infiltrating xenogeneic BPHV tissues express TIMP-1/-2. This suggests that BPHV immune rejection pathophysiology is partially similar to that of calcific aortic stenosis.

Keywords: bioprosthetic heart valves, structural valve degeneration, calcific aortic stenosis, cellular infiltration, lipids, tissue inhibitors of metalloproteinases.

\section{BBEAEHИE}

Несмотря на развитие технологий в медицине, в настоящее время все еще не существует эффективных методов консервативного лечения тяжелых клапанных патологий, поэтому пораженные клапаны сердца заменяют механическими или биологическими протезами [1]. Биологические протезы клапанов сердца (БПК) изготавливают из химически стабилизированных тканей животного происхождения [2]. Они выгодно отличаются от механических аналогов низкой тромбогенностью, однако подвержены структурной дегенерации их биологической составляющей $[3,4]$. Последняя проявляется разволокнением, фрагментацией и кальцификацией волокнистого компонента внеклеточного матрикса (BM) створчатого аппарата, становясь причиной регургитации или стенозирования БПК [3, 4]. Несмотря на современные достижения в области разработки методов химической модификации биоматериала и совершенствование дизайна БПК, данная проблема остается нерешенной, и до половины протезных клапанов требуют замены уже через 15 лет после имплантации пациентам [1].

Любопытно, что результаты современных исследований указывают на схожесть ряда патофизиологических черт структурной дегенерации биоматериала БПК и кальцинирующего аортального стеноза (КАC). Так, возникающие в пораженном нативном аортальном клапане (АК) дегенеративные изменения, связанные с развитием фиброза и кальцификации, обусловлены отложением липидов и макрофагальной инфильтрацией створок [5]. Исследования последних лет демонстрируют, что при дегенерации биоматериала БПК также наблюдается накопление в тканях липидов и иммунных клеток, что сопровождается продукцией матриксных металлопротеиназ (ММП) $[6,7]$. Предполагают, что эти процессы могут вносить заметный вклад в деградацию ВМ протезного биоматериала [8]. В этой связи углубленное изучение патофизиологических закономерностей дегенерации БПК представляет значительный интерес, поскольку потенциально открывает дорогу к разработке меди- каментозной терапии, нацеленной на замедление дегенерации и нативных клапанов сердца и их заменителей.

К одним из факторов, регулирующих ремоделирование ВМ нативных АК, относятся тканевые ингибиторы металлопротеиназ (ТИМП) типа 1 и 2 , сверхэкспрессируемые при КАС $[9,10]$. ТИМП-1/-2 представляют собой многофункциональные белки, которые помимо ингибирования ММП играют роль сигнальных молекул, участвующих в регуляции апоптоза, пролиферации и дифференцировке клеток $[11,12]$. Продукция клетками ТИМП-1/-2, как и ММП, указывает на их ремоделирующую активность в отношении ВМ. До настоящего времени не было опубликовано данных об экспрессии ТИМП в тканях БПК.

Целью настоящей работы явилось изучение клеточной и липидной инфильтрации створок эксплантированных по причине дисфункций БПК, а также выявление экспрессии ТИМП-1/-2 в тканях имплантатов.

\section{MATEPИA^ И METOAЫ}

Материалом для настоящего исследования послужили эпоксиобработанные БПК производства ЗАО «НеоКор» (Россия), иссеченные из аортальной или митральной позиций у 6 пациентов при выполнении операций репротезирования клапанов в 2019-2020 гг. Средний возраст реципиентов при первичном протезировании клапанов составил $54,5 \pm 10,5$ года. Средний срок функционирования изученных БПК - $12 \pm$ 8 лет. Исследование одобрено локальным этическим комитетом НИИ КПССЗ. БПК включены в исследование с учетом наличия подписанного добровольного информированного согласия пациентов. Эндокардит, как причина дисфункции, являлся критерием исключения БПК из данного исследования.

После макроскопического описания БПК, полученных при реоперациях, осуществляли подготовку образцов для исследования материала на микроструктурном уровне. От каждого БПК производили забор центральной части 1-3 створок от основания 
до свободного края, а также участки с выраженными дегенеративными изменениями, которые замораживали при температуре $-140{ }^{\circ} \mathrm{C}$. Затем с помощью криотома Microm HM 525 (Thermo Scientific, Германия) были подготовлены серийные срезы толщиной $6 \pm 1$ мкм, размещенные на предметные стекла по 4-6 штук. В общей сложности изучено 17 образцов от 6 эксплантированных БПК, среди которых были ксеноаортальные протезы «КемКор» $(\mathrm{n}=2)$ и «ПериКор» $(\mathrm{n}=2)$, а также перикардиальные модели «ЮниЛайн» $(\mathrm{n}=1)$ и «ТиАра» $(\mathrm{n}=1)$.

$\mathrm{C}$ целью изучения интенсивности инфильтрации клетками реципиента и определения степени дегенеративных изменений протезного биоматериала срезы окрашивали гематоксилином Джилла и эозином в соответствии с протоколом, оптимизированным для тканей элементов системы кровообращения [13]. Наличие липидов в структуре биоматериала БПК определяли посредством окраски срезов красителем Oil Red (Abcam, Великобритания). Для этого срезы фиксировали в 4\% параформальдегиде (SigmaAldrich, США), затем промывали фосфатно-солевым буфером (ФСБ) (Sigma-Aldrich, США) и инкубировали в изопропаноле в течение 5 минут. Далее их в течение 15 минут окрашивали Oil Red, промывали $60 \%$ изопропанолом и контрастировали с модифицированным гематоксилином Майера (Abcam, Beликобритания). В заключение срезы промывали в водопроводной, а затем бидистиллированной воде и заключали под покровное стекло посредством Mowiol (Sigma-Aldrich, США).

Для типирования клеток и выявления ТИПМ-1/-2 применяли метод ручного иммуногистохимического окрашивания с использованием антител против PTPRC/CD45, CD68, ТИМП-1 и ТИМП-2 (Abcam PLC, Великобритания). Перед окрашиванием срезы 10 минут фиксировали при комнатной температуpe 4\% параформальдегидом с последующей трехкратной отмывкой (по 5 минут) в фосфатно-солевом буфере (ФСБ) (pH 7,4) на шейкере (Polymax 1040, Heidolph, 25 об/мин). Иммуногистохимическую реакцию выполняли с помощью набора NovoLink Polimer Detection System (Leica Microsystems Inc., CША) согласно модифицированному протоколу производителя. Сначала осуществляли блокировку эндогенной пероксидазы 4\% раствором пероксида водорода (Peroxidase Block) в течение 5 минут. 3атем срезы дважды отмывали в ФСБ и блокировали неспецифическое связывание антител $0,4 \%$ солевым раствором казеина со вспомогательными реагентами (Protein Block) в течение 60 минут. Первичные антитела разводили согласно протоколу производителя в $1 \%$ солевом растворе бычьего сывороточного альбумина в пропорциях $1: 1000,1: 2000$ и $1: 3000$ для антител против CD68, ТИМП-1/2 и PTPRC/CD45 соответственно. Срезы инкубировали с антителами в темноте при $+4{ }^{\circ} \mathrm{C}$ в течение ночи, после чего трижды отмывали в ФСБ. При окрашивании на CD68 и ТИМП-2 срезы дополнительно обрабатывали 30 минут противомышиными кроличьими антителами (Post Primary) с последующей трехкратной отмывкой в ФСБ. Далее срезы инкубировали 30 минут с противокроличьими антителами (Novolink Polymer), а затем вновь трижды отмывали в ФСБ и 2 минуты обрабатывали $0,087 \%$ раствором диаминобензидина. Потом срезы отмывали бидистиллятом и помещали в гематоксилин (из набора) на 10 минут. После этого производили подсинение срезов в проточной воде (5 минут), их обезвоживание в трех сменах 95\% этанола (по 5 минут) и просветление в 3 сменах ксилола (по 5 минут), заключая в конце под покровное стекло посредством Витрогель (БиоВитрум, Россия). В качестве контроля использовали интактные эпоксиобработанные ксеноткани: створки аортального клапана свиньи и бычий перикард, приобретенные у ЗАО «НеоКор» (Кемерово, Россия). Также на каждом стекле выделяли по одному срезу с отрицательным контролем первичного и вторичного антител.

Анализ образцов с гистологическими и иммуногистохимическими окрасками осуществляли с использованием светового микроскопа AxioImager. A1 (Zeiss, Германия), обработку изображений производили с помощью программы AxioVision (Zeiss, Германия).

\section{РЕЗУАЬТАТЫ \\ Макроскопическое описание эксплантированных БПК}

БПК, включенные в настоящее исследование, имели признаки первичной тканевой несостоятельности в виде отрывов створок в области комиссур, перфораций, а также признаков кальцификации (рис. 1). Отмечена фиксация створок по стойкам каркаса паннусом со стороны выводного отдела, что способствовало некоторому ограничению их подвижности. Паннус отмечен у 4 из 6 БПК, кальцификация - в разной степени для всех исследуемых имплантатов.

\section{Гистологическое исслелование створок эКсп^антированных БПК}

На микроструктурном уровне дегенеративные изменения биоматериала представлены в виде разрыхления и фрагментации коллагеновых волокон. Инфильтрация протезного биоматериала клетками реципиента выявлена во всех исследуемых образцах 
(рис. 2). Клеточные инфильтраты были локализованы преимущественно на поверхности или в разрыхленных предповерхностных слоях ксеногенного ВМ вблизи основания створок. Проникновение клеток вглубь биоматериала отмечено только для ксеноаортальных протезов, при этом наиболее массивные

$\mathrm{a}$

б

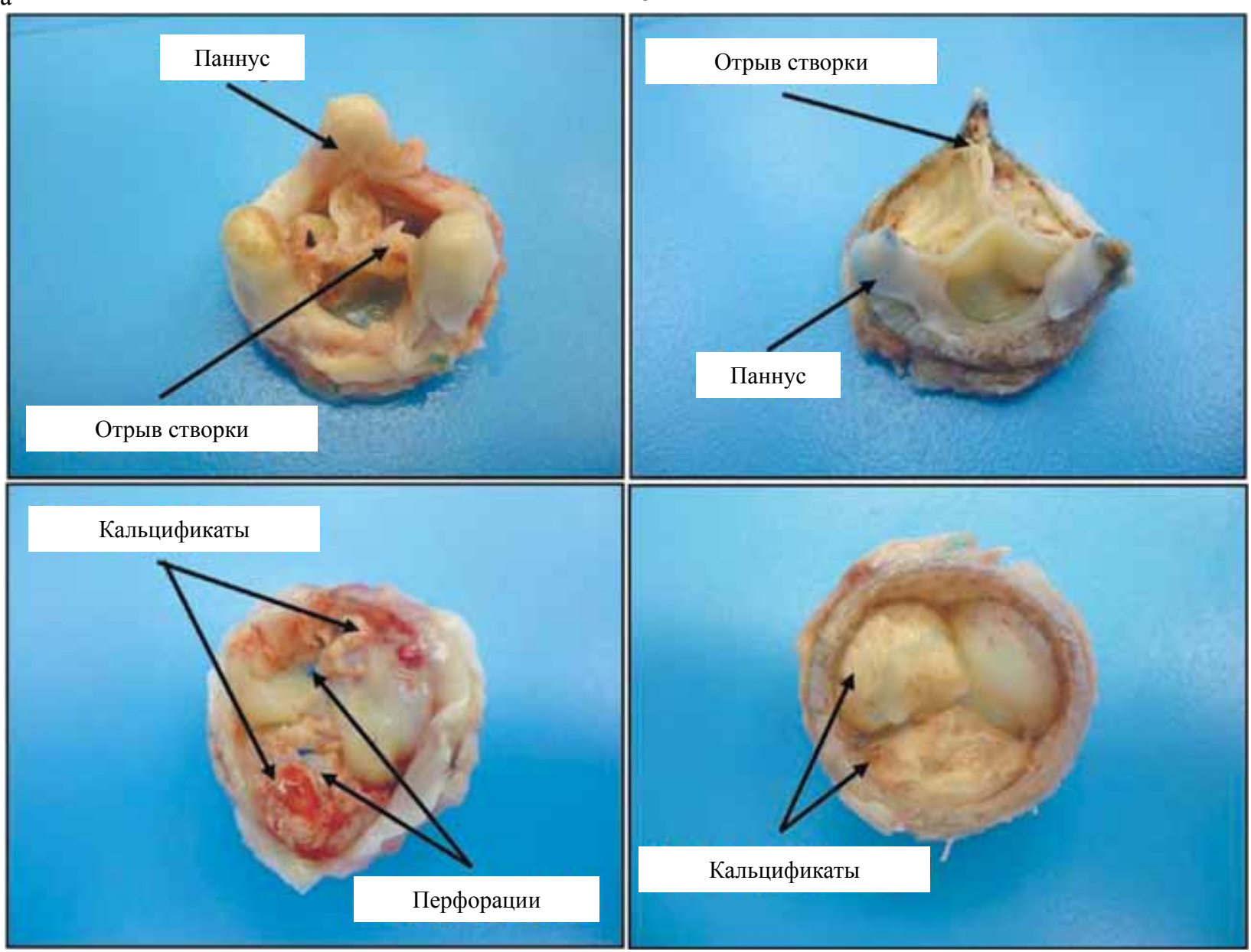

Рис. 1. Биопротезы клапанов сердца, удаленные по причине дисфункции: а - ксеноаортальный протез (ПериКор); б - ксеноперикардиальный протез (ЮниЛайн). Верхний и нижний ряд - вид со стороны выводного и приточного отделов соответственно

Fig. 1. Heart valve bioprostheses removed due to dysfunction: a - xenoaortic prosthesis (PeriCor); $\sigma-$ xenopericardial prosthesis (UniLine). Upper and lower rows - view from the outflow and inflow side, respectively
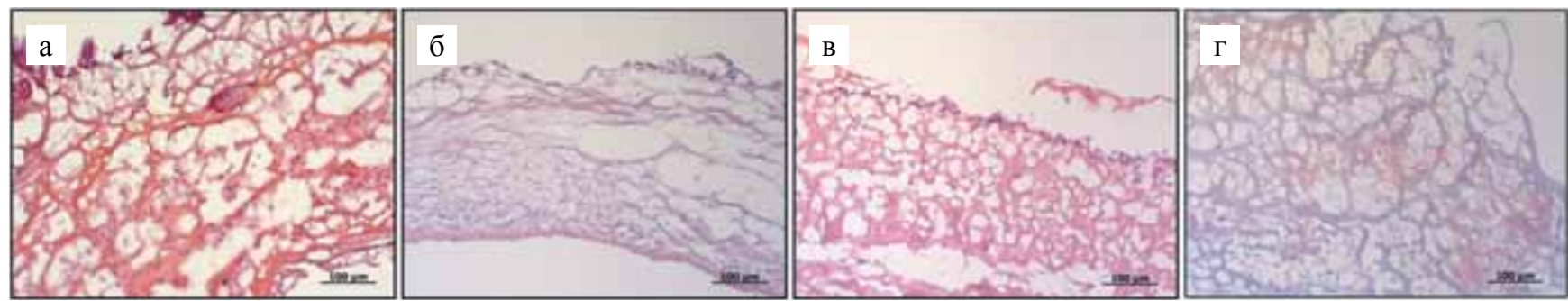

Рис. 2. Клеточная и липидная инфильтрация створок биопротезов клапанов сердца: а - крупный клеточный инфильтрат вблизи кальцификата (окраска гематоксилином Джилла и эозином, Г-Э); б и в - клеточная инфильтрация поверхностных слоев ксеноткани ксеноаортального и ксеноперикардиального протеза соответственно (Г-Э); г - липидные пятна в толще протезных створок (окраска Oil Red)

Fig. 2. Cellular and lipid infiltration of heart valve bioprosthesis leaflets: a - large cellular infiltrate near the calcific (Gill's hematoxylin and eosin staining); 6 and в - cellular infiltration of the surface layers of xenogeneic tissue of the xenoaortic and xenopericardial prosthesis respectively (Gill's hematoxylin and eosin); $\Gamma_{-}$lipid spots in the thickness of the prosthetic leaflets (Oil Red O stain) 
клеточные инфильтраты зафиксированы вблизи перфораций и крупных кальцификатов, где наблюдалось выраженное разволокнение ВМ. В большей степени клеточной инфильтрации биоматериал был подвержен со стороны выводного отдела.

Присутствие липидной инфильтрации в разной степени отмечено для всех исследуемых образцов. При этом локализация липидов не зависела от наличия клеток во ВМ. Образцы интактных эпоксиобработанных ксенотканей не показали положительного окрашивания красителем Oil Red (данные не показаны).

\section{Иммуногистохимический анализ створок эксп^антированных БПК}

Результаты иммуногистохимического окрашивания срезов продемонстрировали, что большинство клеток в инфильтратах коэкспрессируют панлейкоцитарный и макрофагальный маркеры PTPRC/ CD45 и CD68, что позволяет идентифицировать их как макрофаги (рис. 3). Также удалось установить, что эти клетки являются источником ТИМП-1/-2. Положительная окраска на указанные молекулярные агенты отмечена во всех изученных образцах в солокализации с клеточными инфильтратами (рис. 4). Окрашивания на ТИМП-1/-2 в бесклеточном ВМ не отмечено.

Во всех контролях положительной окраски на PTPRC/CD45, CD68 и ТИМП-1/-2 не выявлено (данные не показаны).

\section{ОБСУЖАЕНИЕ}

Полученные данные хорошо согласуются с результатами других оригинальных исследований, направленных на изучение клеточной и липидной инфильтрации ксенотканей БПК $[6,7]$, а также подтверждают выводы, сделанные нашей группой ранее [14]. Окрашивание большинства клеток на маркеры PTPRC/CD45 и CD68 указывает на преобладание макрофагов в составе клеточных инфильтратов, формирующихся в створках БПК. Важно отметить, что макрофаги доминируют вне зависимости от сроков
CD45

a

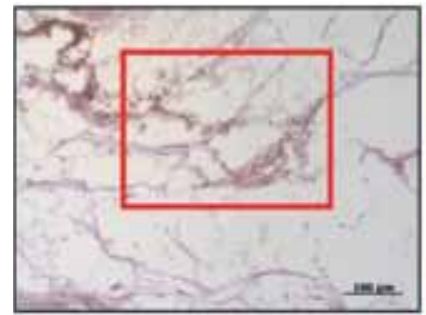

б

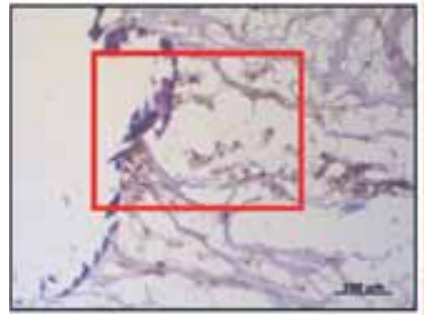

B

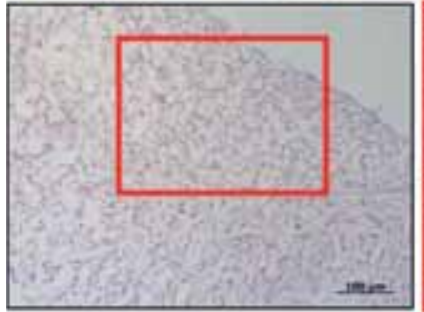

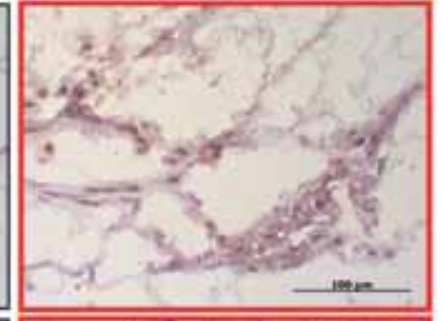
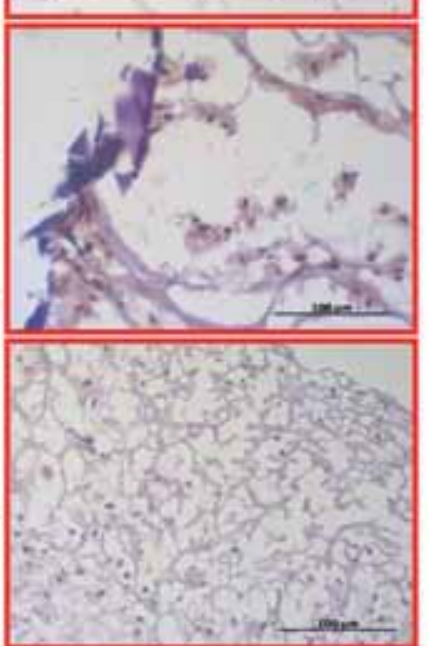

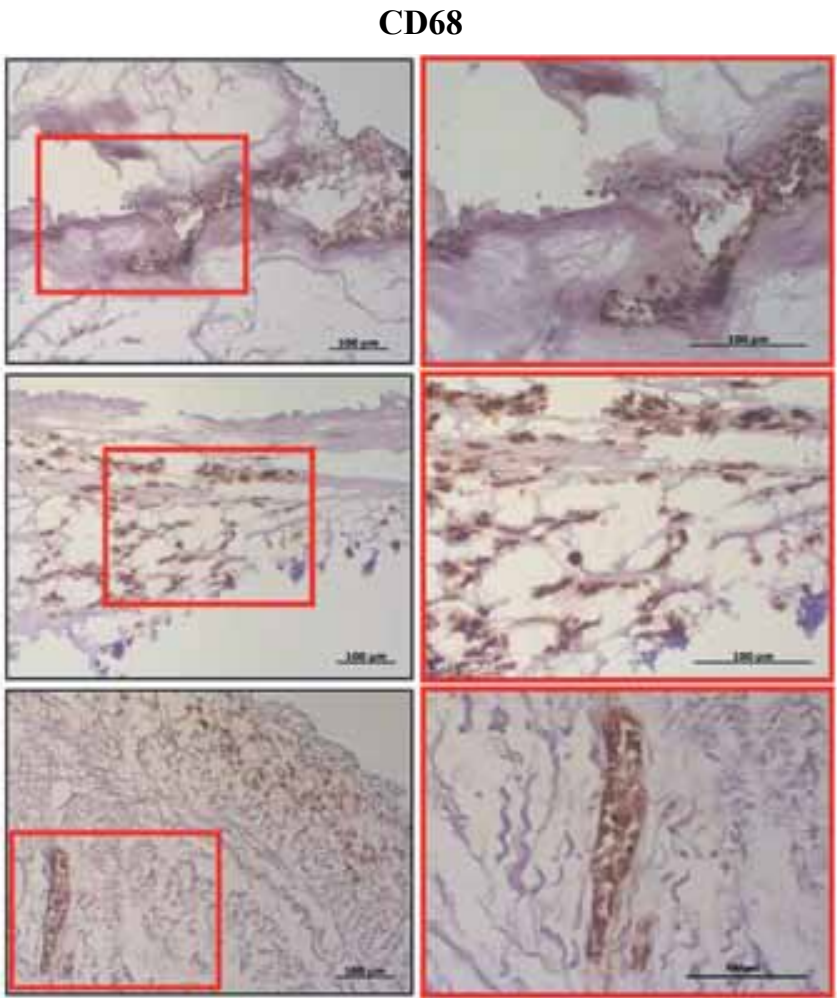

Рис. 3. Результаты иммуногистохимического окрашивания створок биопротезов клапанов сердца на PTPRC/CD45 и CD68: a - скопления иммунных клеток в разрыхленных подповерхностных слоях створок ксеноаортальных протезов; б - крупные воспалительные инфильтраты вблизи кальциевых отложений в створках ксеноаортальных протезов; в - диффузная клеточная инфильтрация поверхностных слоев створок ксеноперикардиальных протезов. Обратите внимание на проникновение макрофагов вглубь ксеноперикарда благодаря псевдососудам

Fig. 3. Results of immunohistochemical staining of cardiac valve bioprosthesis leaflets for PTPRC/CD45 and CD68: a - clusters of immune cells in the loosened subsurface layers of xenogeneic prosthesis leaflets; 6 - large inflammatory infiltrates near calcium deposits in xenogeneic prosthesis leaflets; в - diffuse cellular infiltration of the surface layers of xenogeneic prosthesis leaflets. Pay attention to the penetration of macrophages deep into the xenopericardium due to the pseudovessels 
функционирования имплантатов. Это указывает на хронический тип воспалительной реакции, возникающей в ответ на имплантацию БПК. Любопытно, что воспаление в створках нативных АК, являющееся движущей силой КАС, также имеет хронический характер [5].

Отложение липидов в створках БПК зарубежных и отечественных моделей ранее уже изучали, хотя точный вклад в структурное разрушение протезного биоматериала до сих пор не установлен $[6,15]$. Потенциально накопление липидов может способствовать активации окислительных процессов в створках. Было продемонстрировано, что биологическая составляющая БПК в значительной степени подвержена разрушению через окислительно-зависимые механизмы [16]. Кроме того, поглощение липидов макрофагами стимулирует перерождение последних в пенистые клетки, которые встречаются в тканях БПК [15]. Пенистые клетки секретируют широкий спектр биоактивных соединений, включающий хемокины, митогены и факторы роста, поэтому они могут стимулировать миграцию фибробластов, их пролиферацию и синтез соединительной ткани. Этот процесс свойственен патогенезу КАС, где он ответственен за фиброз и склерозирование створок АК [5]. По-видимому, он также отчасти стоит за формированием паннуса на поверхности БПК.

Нами впервые было установлено, что инфильтрирующие створки БПК клетки экспрессируют ТИМП$1 /-2$, но клиническое значение этого явления пока неизвестно. Эксперименты на нокаутных мышах показывают, что сверхэкспрессия ТИМП-1/-2 имеет антиатерогенное действие за счет подавления активности ММП и уменьшения воспалительного ответа в сосудах [17]. Предполагается, что ТИМП-1/-2 могут играть сходную роль в пораженных нативных АК, при этом увеличение экспрессии данных факторов является рефлекторным механизмом, защищающим ВМ от протеолитической деградации [10]. Экспрессия ТИМП-1/-2 в тканях БПК может иметь как положительное, так и отрицательное значение. Ранее нами было установлено, что инфильтрирующие БПК макрофаги продуцируют ММП [14]. Таким образом, ТИМП-1/-2 могут защищать протезный биоматериал от протеолиза. В то же время снижение активности протеолитических ферментов может способствовать разрастанию соединительной ткани поверх створок БПК. Для проверки представленных гипотез необходимы дальнейшие исследования.

\section{ЗАКАЮЧЕНИЕ}

Ксеногенный биоматериал БПК подвержен накоплению липидов, а также инфильтрации иммунными клетками, которые, в свою очередь, экспрессируют ТИМП-1/-2. Эти наблюдения указывают на частичное сходство патофизиологии структурной дегенерация биоматериала БПК с таковой КАС. Непосредственный вклад ТИМП-1/-2 в развитие дисфункций БПК в настоящее время не установлен и требует изучения.

\section{ТИМП-1}

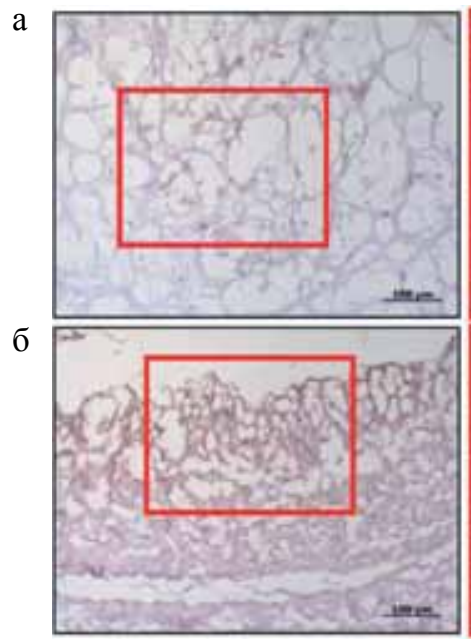

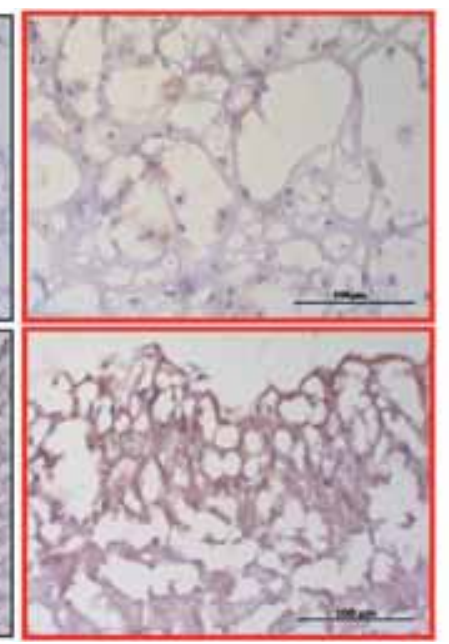

ТИМП-2

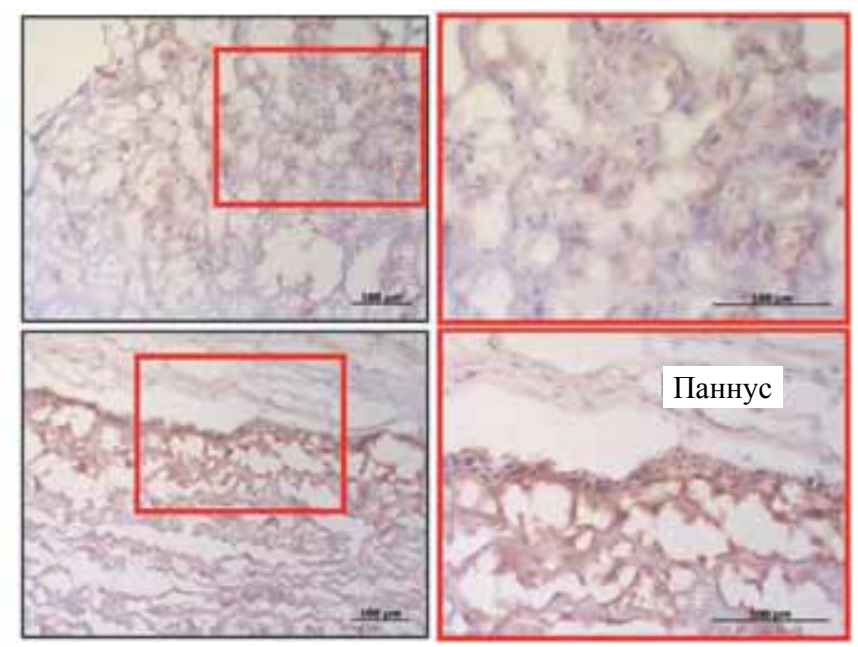

Рис. 4. Результаты иммуногистохимического окрашивания створок биопротезов клапанов сердца на ТИМП-1/-2: а - окрашивание инфильтратов в толще створок ксеноаортальных протезов; б - окрашивание инфильтратов, расположенных в поверхностных слоях биоматериала ксеноперикардиальных протезов

Fig. 4. The results of immunohistochemical staining of heart valve bioprosthesis leaflets for TIMP-1/-2: a - staining of infiltrates in the thickness of xenoaortic prosthesis leaflets; $\sigma$ - staining of infiltrates located in the surface layers of the xenopericardial prosthesis biomaterial 
Настоящая работа выполнена в рамках комплексной программы фундаментальных научных исследований по фундаментальной теме НИИ КПССЗ № 0546-2019-0002 «Патогенетическое обоснование разработки имплантатов для сердечно-сосудистой хирургии на основе биосовместимых материалов, с реализачией пациент-ориентированного подхода с использованием математического моделирования, тканевой инженерии и геномных предикторов».

Авторы заявляют об отсутствии

конфликта интересов.

The authors declare no conflict of interest.

\section{СПИСОК АИТЕРАТУРЫ / REFERENCES}

1. Pibarot P, Dumesnil JG. Prosthetic heart valves: selection of the optimal prosthesis and long-term management. Circulation. 2009; 119 (7): 1034-1048. doi: 10.1161/CIRCULATIONAHA. 108.778886.

2. Овчаренко ЕА, Кльишников КЮ, Глушкова ТВ, Нуштаев ДВ, Кудрявиева ЮА, Саврасов ГВ. Выбор ксеноперикардиального лоскута для створчатого аппарата транскатетерных биопротезов клапанов сердца. Медииинская техника. 2015; 5: 1-4. Ovcharenko EA, Klyshnikov KYu, Glushkova TV, Nushtaev DV, Kudryavtseva YuA, Savrasov GV. The choosing of the xenopericardial patch for transcatheter heart valve. Medical equipment. 2015; 5: 1-4. [In Russ].

3. Capodanno D, Petronio AS, Prendergast B, Eltchaninoff $H$, Vahanian A, Modine $T$ et al. Standardized definitions of structural deterioration and valve failure in assessing long-term durability of transcatheter and surgical aortic bioprosthetic valves: a consensus statement from the European Association of Percutaneous Cardiovascular Interventions (EAPCI) endorsed by the European Society of Cardiology (ESC) and the European Association for Cardio-Thoracic Surgery (EACTS). Eur Heart J. 2017; 38 (45): 3382-3390. doi: 10.1093/eurheartj/ ehx303.

4. Dvir D, Bourguignon T, Otto CM, Hahn RT, Rosenhek R, Webb JG et al. Standardized definition of structural valve degeneration for surgical and transcatheter bioprosthetic aortic valves. Circulation. 2018; 137 (4): 388-399. doi: 10.1161/CIRCULATIONAHA.117.030729.

5. Lindman BR, Clavel MA, Mathieu P, Iung B, Lancellotti P, Otto CM et al. Calcific aortic stenosis. Nat Rev Dis Primers. 2016; 2: 16006. doi: 10.1038/nrdp.2016.6.

6. Shetty R, Pibarot P, Audet A, Janvier R, Dagenais F, Perron $J$ et al. Lipid-mediated inflammation and degeneration of bioprosthetic heart valves. Eur J Clin Invest. 2009; 39 (6): 471-480. doi: 10.1111/j.13652362.2009.02132.x.

7. Simionescu A, Simionescu DT, Deac RF. Matrix metalloproteinases in the pathology of natural and bioprosthetic cardiac valves. Cardiovasc Pathol. 1996; 5 (6): 323-332. PMID: 25851789.

8. Cote N, Pibarot P, Clavel MA. Incidence, risk factors, clinical impact, and management of bioprosthesis struc- tural valve degeneration. Curr Opin Cardiol. 2017; 32 (2): 123-129. doi: 10.1097/HCO.0000000000000372.

9. Bosse Y, Miqdad A, Fournier D, Pepin A, Pibarot P, Mathieu $P$. Refining molecular pathways leading to calcific aortic valve stenosis by studying gene expression profile of normal and calcified stenotic human aortic valves. Circ Cardiovasc Genet. 2009; 2 (5): 489-498. doi: 10.1161/CIRCGENETICS.108.820795.

10. Fondard O, Detaint D, Iung B, Choqueux C, Adle-Biassette $H$, Jarraya $M$ et al. Extracellular matrix remodelling in human aortic valve disease: the role of matrix metalloproteinases and their tissue inhibitors. Eur Heart J. 2005; 26 (13): 1333-1341. doi: 10.1093/eurheartj/ ehi248.

11. Arpino V, Brock M, Gill SE. The role of TIMPs in regulation of extracellular matrix proteolysis. Matrix Biol. 2015; 44-46: 247-254. doi: 10.1016/j.matbio.2015.03.005.

12. Ries C. Cytokine functions of TIMP-1. Cell Mol Life Sci. 2014; 71 (4): 659-672. doi: 10.1007/s00018-013-14573.

13. Богданов ЛА, Кутихин АГ. Оптимизация окрашивания элементов системы кровообращения и гепатолиенальной системы гематоксилином и эозином. Фундаментальная и клиническая медииина. 2019; 4 (4): 70-77. Bogdanov LA, Kutikhin AG. Optimization of hematoxylin and eosin staining of heart, blood vessels, liver, and spleen. Fundamental and Clinical Medicine. 2019; 4 (4): 70-77. [in Russian]. doi: 10.23946/25000764-2019-4-4-70-77.

14. Костюнин AE, Глушкова ТВ. Первые результаты изучения экспрессии матриксных металлопротеиназ-1/-2/-9/-12 в ксеногенных тканях эпоксиобработанных биопротезов клапанов сердца, эксплантированных по причине дисфункций. Российский кардиологический журнал. 2020; 25 (10): 49-55. Kostyunin AE, Glushkova TV. The first results of the study of matrix metalloproteinases-1/-2/-9/-12 expression in xenogenic tissues of epoxy-treated bioprosthetic heart valves explanted due to dysfunctions. Russian Journal of Cardiology. 2020; 25 (10): 49-55. doi: 10.15829/15604071-2020-3978.

15. Kostyunin A, Mukhamadiyarov R, Glushkova T, Bogdanov L, Shishkova D, Osyaev $N$ et al. Ultrastructural pathology of atherosclerosis, calcific aortic valve disease, and bioprosthetic heart valve degeneration: commonalities and differences. Int J Mol Sci. 2020; 21 (20): E7434. doi: 10.3390/ijms21207434.

16. Lee S, Levy RJ, Christian AJ, Hazen SL, Frick NE, Lai EK et al. Calcification and oxidative modifications are associated with progressive bioprosthetic heart valve dysfunction. J Am Heart Assoc. 2017; 6 (5). pii: e005648. doi: 10.1161/JAHA.117.005648.

17. Di Gregoli K, George SJ, Jackson CL, Newby AC, Johnson $J L$. Differential effects of tissue inhibitor of metalloproteinase (TIMP)-1 and TIMP-2 on atherosclerosis and monocyte/macrophage invasion. Cardiovasc Res. 2016; 109 (2): 318-330. doi: $10.1093 / \mathrm{cvr} / \mathrm{cvv} 268$.

Статья поступила в редакиию 27.01.2021 2. The article was submitted to the journal on 27.01.2021 